\title{
Girişimcilik Faaliyetlerinde Endüstri 4.0 Ve Esnek İşletme Etkileşimi: Ballıpınar Çiftliğii*
}

\author{
Mahmut TEKİN** \\ Mustafa SOBA*** \\ Berfu ILTTER****
}

Öz: Çevrelerine uyum sağlamada başarılı görülen girişimlerin en önemli özelliklerinin; uygulamada tercih etmiş oldukları esnek işletme anlayışı olduğunu söylemek mümkündür. Yine bu sayede girişimlerin, ekonomik yaşamda uzun süre varlıklarını koruyabildikleri de ifade edilebilir. Esneklik mucize bir anahtar gibi, girişimlerin konumunu güçlendiren, rakipleri arasında güçlü kılan, yenilikler yoluyla gelişmesine ve büyümesine katkı sağlayan bir detay olarak görülmektedir. Bu bağlamda Endüstri 4.0 olarak adlandırılan 4. Endüstri Devrimi ile esnek işletme modeli etkileşiminin artıları ve eksileri gündeme gelmektedir.

Çalışmanın amacı, girişimcilerin girişimlerinde önemli bir avantaj sağlayan esnek işletme modeli ile Endüstri 4.0 etkileşiminin sonuçlarını değerlendirerek konu üzerinde farkındalık oluşturabilmektir. Bu kapsamda nitel bir çalışma yapılarak, esnek bir girişim olan "Ballıpınar Çiftliği”nin Endüstri 4.0’a bakış açısı üzerine görüşleri incelenmiştir. Sonuç olarak girişimcilerin; girişimlerinin gündeme gelebilecek olan endüstri devrimlerine ve gelişen çevresel koşullara uyum sağlamalarında; yapılanmalarındaki esnek işletme uygulamalarının etkili olabildiği kanaatine ulaşılması mümkün görülmektedir.

Anahtar Kelimeler: Girişimcilik, Esnek İşletme, Endüstri 4.0.

Jel Kodları: M13, M31, M19.

\footnotetext{
"Afyon Kocatepe Üniversitesi Bilimsel Araştırma Projeleri Komisyonunca Desteklenmiştir. Proje No:18.KARIYER.226" ; Çalışma; 5th SCF International Conference on "Economic and Social Impacts of Globalization" and "Future of European Union" 5th-7th September 2018 Podgorica/Montenegro'da düzenlenen konferansta sunulan ve tam metin olarak bildiri kitapçı̆̆ında yayınlanmış olan "Girişimcilik Uygulamalarında Esnek İşletme ve Endüstri 4.0 Uygulamaları" başlıklı bildirinin genişletilmiş halidir.

** Prof.Dr. Selçuk Üniversitesi, IIBF, Işletme Bölümü, mahtekin@selçuk.edu.tr *** Doç.Dr. Uşak Üniversitesi, IIBF, Işletme Bölümü, mustafa.soba@usak.edu.tr

****Dr. Öğr. Üyesi Afyon Kocatepe Üniversitesi, İ̈BF, Uluslararası Ticaret ve Finans Bölümü, berfu@aku.edu.tr
} 


\section{Industry 4.0 And Flexible Business Interaction In Entrepreneurship Activities: Ballipinar}

Farm

Abstract: The most important characteristics of the successful attempts adapt to their environment are; in practice, it is possible to say that they prefer flexible business understanding. It is also possible to state that enterprises can maintain their existence for a long time in economic life. Flexibility is seen as a key to miracle, as a detail that strengthens the position of enterprises, makes it strong among its competitors, and contributes to its development and growth through innovation. In this context, the pros and cons of the flexible business model interaction with the 4th Industrial Revolution called Industry 4.0 comes into question.

The aim of the study is to raise awareness on the subject by evaluating the results of the interaction of Industry 4.0 with the flexible business model, which provides an important advantage for entrepreneurs' initiatives. In this context, a qualitative study was conducted and the views of esnek Ballipınar Farm olan which is a flexible initiative on the perspective of Industry 4.0 were examined. As a result, entrepreneurs; their initiatives to adapt to emerging industrial revolutions and developing environmental conditions; It is seen that it is possible to reach the opinion that flexible business applications in their structuring can be effective.

Keywords: Entrepreneurship, Flexible Business, Industry 4.0.

JEL Classification: M13, M3, M19.

\section{Giriş}

Ekonomi gün geçtikçe daha fazla bilgiyle donanımlı hale gelmektedir. Maddi imkânlar ve emek, ekonomik gücün temel unsuru olma özelliğini yitirmeye başlamıştır. Ekonomik gücün, günümüz şartlarında artık bilgiyle donanımlı olan girişimcinin elinde toplanma eğiliminde olduğu söylemek mümkündür. Yeni ekonomik yapılanmada büyük tesislere, doğal kaynaklara, hammaddelere ya da ucuz iş gücüne hükmedebilmek rekabetçi üstünlük sağlamakta yetersiz görülmektedir (Marangoz, 2012:235). Yaşanılan teknolojik gelişmeler sayesinde günümüzde zenginlik, bilgiyi kullanabilmek ve kontrolü elde tutabilmek ile elde edilmektedir. Marka değeri en yüksek girişimlere bakıldığında 1990'lardan sonra, çoğunluğunun bilgi donanımlarının güçlü olduğu gözlenmiştir (Marangoz, 2014:3). Tarih boyunca yaşanmış olan endüstri devrimlerinin bu aşamaya gelinmesinde etkili olduğunu ifade etmek mümkündür.

Endüstri ya da Sanayi Devrimi, 18. Ve 19. Yüzyıllarda Avrupa'da yeni icatların üretime olan etkisi sonucu; buhar gücüyle çalışan makinelerin, makineleşmiş endüstriyi oluşturması sonucu Avrupa'da yaşanan ekonomik ve sosyal dönüşüm olarak tanımlanmaktadır(Karagül, 
2010: 223). İşgücü yerine su ve buhar gücüyle çalışan mekanik sistemlerin kullanımı ile birinci endüstri devrimi başlamıştır. İkinci endüstri devrimi 20.yy’lın başlarında; işbölümüne dayalı, elektrik enerjisinin kullanıldığı ilk üretim hattında kitlesel üretimin yapıldığı dönemdir. Üçüncü sanayi devrimi ise 1970'li yılların başından itibaren imalatın otomasyonunu ileri safhalara taşımayı başaran elektronik ve bilgi teknolojilerinin devreye girmesi ile gündemdeki yerini almıştır. $\mathrm{Bu}$ süreçte atom enerjisi, bilgisayar, fiber-optik ve çip gibi mikro- elektronik teknolojisine dayalı gelişmeler söz konusu olmuş ve olmaktadır. Endüstri 4.0 olarak da adlandırılan 4.Sanayi Devrimi'nde siber-fiziksel sistemlere dayalı üretim gerçekleştirilmektedir (Kagerman vd, 2013:13-14).

Endüstri 4.0 kavramının ortaya çıkmasında; dijital dünyada meydana gelen önemli gelişmeler, bu gelişmelerin ortaya çıkardığı siber-fiziksel sistemler, nesnelerin interneti adı verilen ve birbirleriyle iletişim kurabilen milyarlarca cihaz, büyük veri işleme yeteneği gibi bir çok unsur etkili olmuştur (Soylu, 2018:44). Endüstri 4.0, birbiriyle iletişim kurabilen nesnelerin, makinaların yer aldığı akıllı sistemler (fabrika, ev , çiftlik vb.) vasıtasıyla, daha esnek, düşük maliyetli, hızlı ve verimli üretim yapılabilmesini hedeflemektedir. Eş zamanlı veri alışverişi sayesinde kitlesel kişiselleştirmeye imkân sağlayan tasarım, üretim ve dağıtım sistemlerinden fabrika vb. üretim merkezlerinin yanısıra tüm toplumun etkilenmesi söz konusu olmaktadır (Kılıç ve Alkan, 2018:32). Bu bağlamda nesnelerin interneti uygulaması tarım ve ziraat faaliyetlerini de kapsamaktadır.

Nesnelerin İnterneti uygulaması için özellikle seralar, çiftlikler gibi kapalı alanların ve ortama ait verilerin nispeten denetlenebileceği, farklı tarımsal ve hayvancılık faaliyetlerinin gerçekleştirilmesinde ideale yakın olabilecek koşulların oluşturulmasına yönelik işlemlerin çift yönlü işlemesine iyi bir örnek teşkil etmektedir. Bir serada ya da çiftlikte ortam sıcaklığı, nem, hayvan vücut 1sısı günlük beslenme miktarları ve süt sağım verileri gibi değerleri, makineler arası ağlar ile merkezi bir internet ortamında ya da bilgisayarda depolanması, değerlendirilmesi ve veriyi kullananların kendi mobil uygulamaları veya web erişimleri yoluyla kontrol edilmesi mümkündür (Zhao et al, 2010;Aktaran Ercan ve Kutay, 2016:603) .

Çalışma kapsamında girişimcilik, esnek işletme ve Endüstri 4.0 kavramlarına yer verilerek konu ile ilgili bir çiftlik incelemesi yapılmıştır. Çiftlik sahibi girişimcinin çiftlikteki mevcut esnek işletme modeli yapılanmasının Endüstri 4.0 uygulamalarına katkısı ve Endüstri 4.0 uygulamaları hakkındaki düşünceleri, çiftliğin bu uygulamayı mümkün kılan teknolojiye ne kadar uyumlu olduğu ve uygulamanın tamamlanma derecesi belirlenmeye çalışılarak, değerlendirmelerde bulunulmuştur. 


\section{Girişimcilik}

Girişimci, yeni bir fikir ya da bir girişim planına sahip ve bu planını gerçekleştirdiğinde ortaya çıkabilecek risklerin ve giderlerin farkında olan kişidir. Ancak karşılığında alacağı maddi gelirin farkındalığı da girişimci enerjisinin en büyük etkenlerinden birisi olmaktadır. Girişimci tek bir bakış açısından öte, derin düşünerek, olayların farklı taraflarını da görebilir, bu bağlamda fikir üretme aşamasına geldiğinde karşılaştığı problemi farklı yönlerden gözlemleyebilir. Dolayısıyla girişimci, seçtiği hedef kitlede bulunan bütün düşünce tarzlarına uygun çözüm geliştirebilir (Ergen, 2014: 36).

Girişimciliğin öneminin artması, iktisadi ve sosyal gelişme bakımından hayati önem taşımasından kaynaklanmaktadır. Her geçen gün artan girişimci faaliyetler, durgun ekonomileri harekete geçirmekte ve yeni iş alanlarının oluşturularak, istihdam sorunlarının çözümünde etkili olmaktadır. Girişimci faaliyetler ayrıca teknolojik gelişmenin ivmesini artıran itici bir güçtür (Aytaç ve İlhan, 2007:101 ).

Bilgisayar ve internet teknolojisindeki ilerlemelere bağlı olarak, girişimcilik çabalarının gerçekleşme şartlarında da önemli değişimler ve gelişmeler gündeme gelmektedir. Eskinin girişimcilik algısında üç temel unsur olan; toprak, sermaye ve emek girişimcinin cesaret ve becerisinden bağımsız olan üç temel unsur olarak görülmekteydi. Başka bir ifadeyle, eğer girişimci bu üç temel usura sahip değilse, risk alması, cesur ya da firsatları değerlendiren girişimcilerin bu becerileri, dikkate değer iş büyüklükleri yaratamıyordu. Ancak, bilgi çağının getirdiği gelişmelerle günümüz girişimcisi için şartlar çok daha olumlu görülmektedir. Zaman içerisinde, küçük ya da büyük iş girişimleri için yukarda sayılan üç faktör de geçmişle kıyaslandığında önemini yitirmiş, bunların yitirdiği değerin yerini; "iş fikri” ve "girişimcilik" unsurlarına bıraktığını ifade etmek mümkündür (Halıcı, 2008:2).

Girişimcilerin bilgi toplumuna dönüşümle birlikte iş yapma biçimleri değişmiş, ekonomik ve beşeri sermayelerinin yanında sosyal ve kültürel sermayelerinin de önemi ortaya çıkmıştır. Girişimcinin başarısını büyük ölçüde belirleyen girişimcinin sermayesinin dört alt sermayeden oluştuğu görülmektedir. Bu konudaki kavramsallaştırmaya ilişkin şekil aşağıda yer 

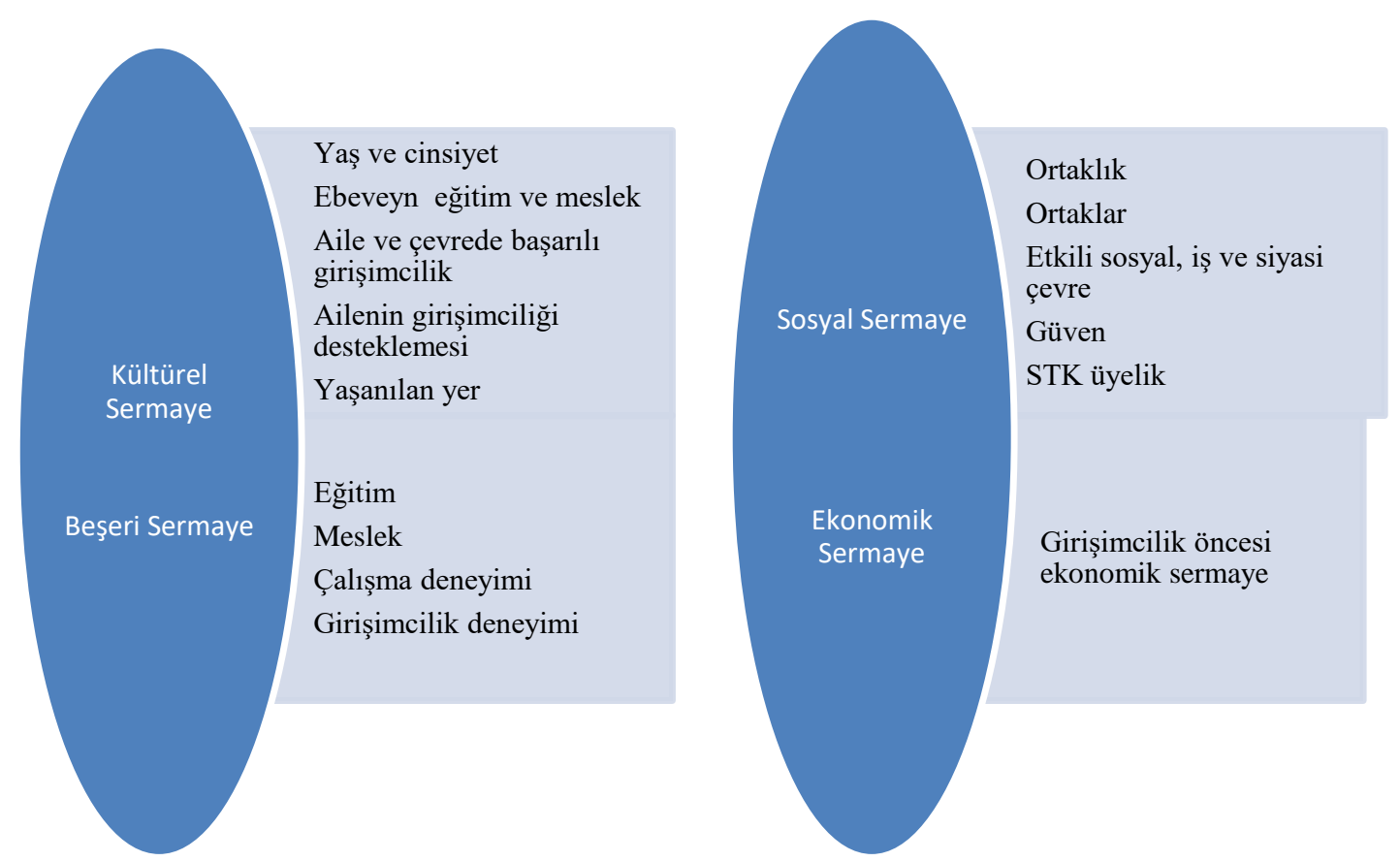

Şekil 1: Teknoloji Tabanlı Girişimcilerin Sahip Oldukları Sermaye

Kaynak: (Cansız, 2017:64)

Girişimciler, girişimcilik faaliyetleri süresince bir sistem içerisinde yer alırlar. $\mathrm{Bu}$ sisteme girişimcilik ekosistemi adı verilmektedir. Girişimcilik ekosistemi; girişimcinin yaşam döngüsünde de zaman içerisinde onu besleyen, koruyan, geliştiren bir sistem oluşur. Her ekosistemde olduğu gibi, girişimci bu sistem içerisinde daha sağlıklı ve ve verimli bir hayat sürer (Özkaşıkçı, 2013:109). Girişimcilik ekosisteminin tüm girişimciler için aynı olduğu düşünüldüğünde, bazı girişimcilerin diğerleri ile karşılaştırıldığında daha başarılı oldukları görülmektedir. Bu durumu, girişimcilerin sahip oldukları sermaye bileşenleri ile açıklamak mümkündür. Aslında, Türkiye'deki teknoparklarda faaliyet gösteren girişimcileri eyleme yönlendiren; kültürel, sosyal, beşeri ve ekonomik sermaye faktörlerinin birleşik etkisi oluşturmaktadır (Cansız ve Ulusoy, 2017:121).

Toplumsal ve ekonomik yaşamın hareketlenmesinde girişimcilik oldukça önemli bir unsur olarak görülmektedir. Çağın gereksinimleri göz önüne alındığında girişimcinin gücünün; yenilik yaparak, yaptığı yeniliği iş dünyasında somut ticari ürünlere dönüştürebilme yeteneğine dayandığını ifade edilebilir. Bu kapsamda günümüz girişimcisi, girişimcilik faaliyetlerinde ekonomik ve sosyal çaba göstermektedir (Marangoz, 2016: 85-93): 
- Ekonomik çabalar; yeni ürün ve hizmet geliştirme, ürün çeşitliliği sunabilme, üretim yöntemleri geliştirme, istihdam yaratma, sermaye birikimine katk1, refah düzeyinin yükseltilmesi, vb. olarak değerlendirilebilir.

- Sosyal çabalar; toplumsal dönüşümü gerçekleştirme, topluma hareketlilik kazandırma, toplumsal itibar ve sosyal sorumluluk algısı oluşturma gibi sıralamak mümkündür.

Dolayısıyla girişimcilik faaliyetleri hem mikro hem de makro anlamda düşünüldüğünde güçlü bir küresel ekonomi için gerekli bir çaba olarak görülmektedir (Scarborough, 2014:2). Bu bağlamda ulaşılması gereken nokta; yenilik ve girişimciliğin sıradan, istikrarlı ve devamlı olduğu girişimci bir toplumdur. Yenilik girişimcilerin özel aracıdır; girişimciler bu araç yardımıyla farklı bir iş ya da hizmet fırsatı olarak değişimden yararlanmaktadırlar. (Drucker, 2017:295). Girişimciler bu özellikleri sayesinde söz konusu olabilecek herhangi bir endüstri devrimine uyum hususunda; çevrelerindeki firsatları ve tehditleri gözlemleyerek, girişimlerinin üstün yönlerini ön planda tutarak, zayıf yönlerini bu gelişmelerle başa çıkabilecek şekilde yeniden gözden geçirebilirler. Bu sayede yeni koşullara uyum sağlamakta zorluk yaşamazlar.

\section{Esnek İşletme Kavramı}

Küresel rekabet ortamında faaliyet gösteren girişimciler, varlıklarını sürdürebilmek, rekabet güçlerini artırmak ve yeni pazarlara girebilmek için tüm iş süreçlerini esnekleştirmeleri gerekmektedir. Esnek işletme kavramı; bir işletmenin tüm birimleriyle birlikte çevresine uyum gösterebilen; tüketicilerin istek ve beklentilerindeki farklılıklara farklı çözümler üretebilme yeteneğine sahip olabilmekle açıklanabilir (Tekin ve Zerenler, 2007: 24). Diğer bir anlatımla esnek işletme, bir işletmenin tüketiciler, tedarikçiler ve rakipler gibi tüm çevresel aktörleri tanıması, anlaması ve buna göre kendini daima güncelleyerek yeni pozisyonlar almasıdır (Sethi ve Sethi, 1990: 289).

Esneklik, üretilen parça türlerinin fazla olması ve üretimin miktar ve türünün gerektiğinde kolaylıkla değiştirilebilmesidir. Üretim esnekliğgi, bir işletmenin üretebileceği parça türünü değiştirebilme yeteneğidir. Esnek üretim sistemleri, robotların oldukça kısa bir sürede üretim yapabildiği, montaj hattının olmadığı, parçaların hızla uygun yerleri bularak arka arkaya üretime yöneldiği ve bu süreçte insanların bu ortama uyum sağladığı bir yapıdır. $\mathrm{Bu}$ sistemlerde bir ya da birden fazla amaçlı bilgisayar kontrollü makinelerden oluşan imalat hücreleri bulunmaktadır. Parçaların makinelere yerleştirilmesi ve bir makineden diğerine taşınması, robotlar ve karmaşık transfer mekanizmaları ile gerçekleştirilmektedir (Marangoz, 2016:384). 
Esnek işletme ya da girişim, uygulamada yaygın bir kullanım alanı bulan "esnek üretim sistemleri”ni çağrıştırmasına rağmen tamamıyla bu sistemden oluşmaz. Bir işletme; organizasyonel esnekliğe sahip değilse, üretim alt yapısının esnek olması girişimin performansına önemli katkılar sağlamayabilir. Aksine, işletmenin yönetim kadroları; yaratıcı, yenilikçi, çevresel belirsizliklere karşı esnek stratejiler uygulayabilen, öğrenen, kendini daima geliştiren bir yapıda olmasına karşın üretim etkinlikleri bu esnekliği gösteremiyorsa benzer olumsuz sonuçların alınması mümkün olabilir (Tekin ve Zerenler, 2007: 24-25).

“ Teknoloji ve yenilikçilik, esnek işletme örgütlenmesinin merkezinde yer alan kavramlar arasındadır. Dünyada başarılı endüstri bölgelerinin en önemli özellikleri; ar-ge’ye dayalı etkin yenilikçilik stratejileri üreterek, esnek üretim teknolojilerinin yaygın olarak kullanmalarıdır. Farklı yapılarda esnek işletme modellerinden söz edilebilir. İşletmenin yönetsel ve mühendislik alanlarının entegre bir şekilde çevresel değişime uyum sağlayabilme adına dinamik bir yapıda olabilmek için yeniden yapılanma süreçlerini içermesi modellerde öne çıkan temel özellik olarak görülmektedir. Esnek işletme modellerini genel anlamda dört farklı yapıda incelemek mümkündür (Tekin ve Zerenler, 2007: 26-27):

- İşletmelerin yeni üretim teknolojilerini kullanarak organizasyonel ve üretim yapılarında yeni örgütlenmeye gitmeleri ve emeğin kullanım biçimini değiştirerek üretim ölçeğini değiştirmeden, çeşit ve farklılık odaklı "esnek organizasyon” modeli,

- İşletmelerin giderek belirsizleşen ve sürekli değişen çevresel koşullara uyum sağlama ve üretim maliyetlerini azaltma amacıyla, dış kaynaklardan yararlanmaya dayalı "fason üretim" modeli,

- Belirli sosyokültürel özellikleri ve geçmiş deneyimleri olan yerel mekanlarda yerel düzeydeki toplumsal ve kültürel yapıdan yararlanarak kümelenmeler (sanayi odakları) oluşturan "endüstriyel üretim ağları" modeli,

- Bilişim teknolojileri odaklı, işletmenin yönetsel ve mühendislik örgütlenmesini bilişim altyapısına göre yapılandıran "bilişim odaklı işletme" modeli.

İşletmelerde esnek üretim sistemlerinin beraberinde getirdiği bir takım avantaj ve dezavantajlar bulunmaktadır. Aşağıdaki Tablo 1.'de” avantaj ve dezavantajlar yer almaktadır.

Tablo 1: Esnek Üretim Sistemleri Avantaj ve Dezavantajlar

\begin{tabular}{|l|l|}
\hline AVANTAJLAR & DEZAVANTAJLAR \\
\hline Üretim süresinin azaltılması & Maliyetin yüksek olması \\
\hline Süreç envanterinin azaltılması & İstihdamın olumsuz etkilenmesi \\
\hline
\end{tabular}




\begin{tabular}{|l|l|}
\hline Tezgah kullanılabilirliğinin artması & Sürekli teknolojik yenilik gerektirmesi \\
\hline $\begin{array}{l}\text { Farklı parçaların konfigürasyonlarının } \\
\text { sağlanma olanağı }\end{array}$ & Planlama yetersizlikleri \\
\hline Çalışan işçi sayısının azalması & Entegrasyon sorunları \\
\hline Küçük parti üretimine olanak verilmesi & \\
\hline Yarı mamul stoklarının azalması & \\
\hline Esneklik sağlanması & \\
\hline Kalitenin artırılması & \\
\hline Verimlilik artışının sağlanması & \\
\hline
\end{tabular}

Kaynak: (Tekin ve Zerenler, 2007:214-217).

Tablo 1 incelendiğinde esnek üretim sistemlerinin avantajlarının dezavantajlarından daha fazla olduğu görülmektedir. Girişimciler işletmelerinin tüm işleyiş aşamalarında esnek bir yapıya sahip olmalıdır. Ancak bu esnek yapı sağlanırsa pazardaki değişim algılandığında cevap verebilmek mümkün olabilir.

\section{IV.Endüstri 4.0}

Toplum hayatındaki dönüşüm, avlanma ve basit tarımsal üretime dayalı ilkel toplumdan, sanayi toplumuna ve daha sonra da bilgi toplumuna geçiş olarak gerçekleşmiştir. Konuya küresel boyutta bakıldığında dünya üzerinde tarım, sanayi ve bilgi toplumunun eş zamanlı olarak bulunduğunu belirtmek gerekmektedir. Nasıl bir toplumun tamamı homojen olarak aynı toplumsal yapıya sahip değilse, küresel boyutta da çok sayıda toplumun aynı ekonomik yapıya sahip olmadığını söylemek mümkündür. İlk çağlarda dünyadaki bütün toplumların homojen olarak tarım toplumu özelliğine sahip olmalarına rağmen, ilerleyen dönemlerde bazı toplumların sırayla sanayi ve bilgi toplumu aşamalarına geçtikleri görülmektedir (Karagül, 2010: 219).

Tablo 2 : Sanayi Toplumu ile Bilgi Toplumu Arasındaki Farklılıklar

\begin{tabular}{|l|l|l|}
\hline Dönüşen Faktörler & Sanayi Toplumu & Bilgi Toplumu \\
\hline Üretim ve Rekabet & Ulusal & Küresel \\
\hline Örgütsel Yapı & Hiyerarşik Bürokratik & Ăg Örgüsü, Şebeke \\
\hline Üretim Yapısı & Kitlesel üretim & Zamanında Esnek Üretim \\
\hline Büyümenin Dinamikleri & Sermaye İşü̈cü & Yenilik, İcatlar ve Bilgi \\
\hline Teknolojiyi Belirleyenler & Makineleşme & Dijitalleşme \\
\hline
\end{tabular}




\begin{tabular}{|l|l|l|}
\hline İşü̈cü Politikasının Amacı & Tam İstihdam & Ÿ̈ksek Reel Ücret \\
\hline Gerekli Eğitim & Mesleki Diplomaya Yönelik & Yaşam Boyu Öğrenim \\
\hline İşgücünün Yapısı & Belirli Bir Alanda Uzman & $\begin{array}{l}\text { Bilgi, Deneyim, Çok Yönlü } \\
\text { Beceri, Yenilikçi, Yaratıcı }\end{array}$ \\
\hline Sektörel Yapı & $\begin{array}{l}\text { Tarım, Sanayi Sektörü } \\
\text { Ağırlıkı }\end{array}$ & Hizmet Sektörü Ağırlıklı \\
\hline
\end{tabular}

Kaynak: (Karagül, 2010:233)

Tablo.2'de Sanayi devriminin oluşturduğu sanayi toplumundan bilgi toplumuna geçilmesinde yaşanan dönüşümler görülmektedir.

İlk sanayi devrimi (1.0) su ve buhar gücünü kullanarak mekanik üretim sistemleri ile ortaya çıkmıştır. İkinci sanayi devrimi (2.0)'da elektrik gücünün yardımıyla seri üretim tanıtılmıştı. Üçüncü sanayi devriminde (3.0) ise dijital devrim, elektroniklerin kullanımı ve BT (Bilgi Teknolojileri)'nin gelişmesiyle üretim daha da otomatik hale geldi. Dördüncü sanayi devriminde (4.0) sanal ve fiziksel sistemlerin entegre olarak kullanımı söz konusudur. Endüstri 4.0, "Nesnelerin İnterneti” kavramının doğduğu bir süreçtir. Teknolojik gelişmeler önce bilgisayarları sonra insanları birbirine bağlamış durumdadır. Nesnelerin İnterneti çerçevesinde nesnelerin birbirleri ile bağlanması söz konusudur. Bu teknoloji nesnelerin - tıpkı insanlar gibi - kablosuz olarak bir ağa bağlanıp veri paylaşabileceği, inisiyatif alarak karar verebileceği, bir aksiyon başlatabileceği yeni bir endüstri devriminin kapılarını aralamaktadır. (Meydanoğlu ve Klein,2016:12-13).

2012 yılında Alman Hükümeti tarafından oluşturulan Çalışma Grubu'nun hazırlayarak 2013 yılında sunulan nihai rapora göre Endüstri 4.0 geçiş süreci yaşanmaktadır. Süreçte başarılı olunabilmesi için gereken sekiz aşama bulunmaktadır. Raporda belirtilen bu aşamaları; “(1)Referans donanım rehberinin belirlenmesi ve standardizasyon, (2) Karmaşık yapıların yönetilebilmesi, (3) Kapsamlı ve yüksek hızlı bir haberleşme altyapısının endüstriye sağlanması, (4) Emniyet ve güvenlik, (5) Çalışma organizasyonu ve tasarım, (6) Eğitim ve profesyonel gelişimin sürekliliği, (7) Mevcut mevzuatın uyarlanması, (8) Kaynakların verimli kullanılması" olarak ifade etmek mümkündür (Kagerman vd., 2013;49-50).

Dördüncü sanayi devrimi kavramı otomasyonun, yani üçüncü sanayi devrimindeki sistemlerin daha akıllı olmasına dayanan bir kavramdır. Akıllı fabrikalar ifadesi; bütün fiziksel sistemlerin otomatikleştirilmesi ve uzaktan takip edilebilir olması anlamındadır (Özdoğan, 2017:28). Akıllı fabrikalarda akıllı üretimin altyapısını siber fiziksel sistemler ve nesnelerin interneti oluşturacaktır. Bu bağlamda tek tek farklı bilgisayarlar tarafından kontrol edilen 
makineler ana bir bilgisayar tarafından izlenecektir. Bu fabrikalarda yeni teknolojiler sayesinde karmaşık süreçler simüle edilebilecek ve tüketicinin ihtiyaçlarına zaman kaybetmeden sorunsuz bir şekilde uyum sağlanabilecektir. Bu uygulama ile ciddi ölçüde zaman ve maliyet avantajı sağlanarak, tedarik zinciri ve akıllı fabrikaların zaman kaybı olmadan üretimi optimize etmeleri mümkün olabilecektir (Aktop ve Aktop, 2017:135).

Tablo 3: Endüstri 4.0'1n Pozitif ve Negatif

\begin{tabular}{|c|c|}
\hline Pozitif Etkiler & Negatif etkileri \\
\hline $\begin{array}{l}\text { Üretim performansının gerçek zamanlı } \\
\text { izlenebilirliği }\end{array}$ & $\begin{array}{l}\text { Endüstri 4.0'1 yakalayamayan işletmelerin } \\
\text { yok olması }\end{array}$ \\
\hline $\begin{array}{l}\text { Ürünlerin kalite, standart ve estetik seçenekleri } \\
\text { için çözümler bulmak }\end{array}$ & $\begin{array}{l}\text { Sistem yeteneği nedeniyle işgücünün } \\
\text { istihdamının azalması }\end{array}$ \\
\hline $\begin{array}{l}\text { Fabrika ve işletmeleri uzaktan yönetebilme } \\
\text { yeteneği }\end{array}$ & $\begin{array}{l}\text { Kamu hizmetlerinin belli bir seviyede } \\
\text { olmadığı ülkeler üzerindeki sınırlı etkiler }\end{array}$ \\
\hline Artan müşteri deneyimi & Veri depolamadaki zorluklar \\
\hline Yeni teknoloji devlerinin ortaya çıkış1 & $\begin{array}{l}\text { Verileri yönetemeyen işletmelerin yok } \\
\text { olması }\end{array}$ \\
\hline $\begin{array}{l}\text { Tüm cihazların dijitalleştirilmesi, aralarında ağ } \\
\text { oluşturulması }\end{array}$ & İstihdam açısından dezavantajlar \\
\hline Artan iş gücü kalitesi & El işleri yeteneğinin zayıflaması \\
\hline $\begin{array}{l}\text { Daha hızlı, daha verimli ve kişiselleştirilmiş } \\
\text { ürünler sağlamak }\end{array}$ & \\
\hline
\end{tabular}

Kaynak: (Yüksel ve Sener, 2017:298).

Tablo 3 incelendiğinde, Endstri 4.0'^n girişimcilerin girişimlerine yapmış oldukları katkının öncelikle girişimleri, sonrasında toplumları sosyal ve ekonomik açıdan ve ülkeleri de sürdürülebilir kalkınmayı gerçekleştirme hususunda önemli ve olumlu sonuçları olduğu görülmektedir. Ancak Endüstri 4.0 yapılanmasını yakalayamayan girişimler yok olabilirler. İstihdam açısından olumsuz bir yapılanma olarak görülen bu yapılanma aslında beraberinde yeni iş fırsatları ve nitelikli işgücü açısından da fırsatları beraberinde getirebilir. Zira tehditleri fırsata dönüştürebilme yeteneği girişimcilerin özellikleri arasında yer almaktadır. 


\section{Girişimcilik Uygulamalarında Esnek İşletme ve Endüstri 4.0 Etkileşimi}

Girişimci, mal ya da hizmet üretmek ve/veya pazarlamak için sahip olduğu sermayeyi tehlikeye atar ve başkalarının sermayesinden yararlanır. Tek başına kendi emeğini kullanabileceği gibi başkalarının emeğini satın alarak da çalışabilir. İşletmenin amacına ulaşabilmesi için girişimci, insanların istek ve ihtiyaçlarındaki gelişmeleri en iyi biçimde görebilen bir kişi olmalıdır. Ayrıca, girişimci yeni mallar ortaya koymak ve yeni üretim yöntemleri uygulama yeteneğine sahip olmalıdır (Cemalcılar vd, 2000: 4).

İşletmelerin bir sistem olarak esnek bir yapıda olmaları; pazardaki rekabet ve değişimin algılanarak, değişime cevap verebilmesini mümkün kılmaktadır. Esneklik kavramı, işletmelerin rekabet gücüne katkısı yönünde ele alındığında; hareket esnekliği ve durum esnekliği olarak ikiye ayrilabilir (Tekin ve Zerenler, 2007: 185-186);

- Hareket esnekliği, işletmelerin değişen rekabet koşullarına tepki verebilmesi için yeni faaliyetlerde bulunabilme derecesi olarak tanımlanabilir,

- Durum esnekliği; rekabet koşulları değiştiği halde verimli olarak üretim yapmaya devam edebilme yeteneğidir.

Günümüzde işletmelerin rekabet güçlerini koruyabilmeleri, kalite, hız, esneklik, sürekli gelişim ve çeşitlilik bileşenlerine daha fazla önem vermelerini gerekli kılmaktadır. Tüketicilerin istek ve ihtiyaçlarının belirlenmesinde, ürün ve hizmetlerin tasarımında, üretiminde ve sevkiyatında hız önemli bir unsur haline gelmiştir (Top, 1996:21). Bu hızlı değişim sürecine uygun olarak tüketici tercihlerinde gerçekleşen farklılıklar da arz ve talebi daha esnek bir yapıya dönüştürmektedir. Dolayısıyla girişimciler bu yapıya uygun üretim sistem ve teknolojileri seçmek durumundadırlar (Aydeniz, 1997:15).

Akıllı cihazların, birbirlerini algılayan ve iletişime geçebilen nesneler aracılığıyla akıllı bağlantısı, "Nesnelerin Interneti” olarak adlandırılmaktadır. Bu teknoloji ile çok sayıda, küçük boyutlu, kablosuz teknoloji kullanabilen algılayıcı aletlerin desteği ile yaşanılan çevredeki (ev, okul, işyeri, fabrika, şehir vb.) hemen hemen bütün olayların izlenmesi ve bilgi alınması mümkündür. Benzer olarak üretim/imalat ile ilgili endüstriyel sistemlerden aktarılabilecek gerekli verilerin eş zamanlı kullanımı mümkün kılınmaktadır. Bu sayede ortamdaki algılayıcı cihazlardan ve üretimdeki veri terminallerinden gelen, gerçek zamanlı sürekli veri akışı, internet ortamında Bulut Servis Sağlayıcılar tarafından verilen depolama, veritabanı, uygulama hizmetleri ile Bilgi Sistemleri tarafından kullanılmaya hazır hale getirilmektedir. Böyle bir bilgi akışı iş hayatını ve endüstriyel üretim sistemlerini olumlu yönde etkileyebilecek değişikliklere neden olmaktadır. Üretimde kullanılan akıllı cihazlar, insan hatasını en aza indirerek, gerçek zamanlı bilginin karar destek sistemleri tarafından değerlendirilmesini sağlayacaktır. Bu da 
üretimde kalitenin arttırılması, maliyetlerin azaltılması, rekabetçi ürünler yaratılması gibi birçok olumlu etki yaratacaktır (Ercan ve Kutay, 2016:599).

Dolayısıyla hızla ilerleyen teknolojik gelişmelerin bir sonucu olan "Akıllı Fabrikalar" ile gündeme gelen Dördüncü Sanayi Devrimi girişimcilere yeni ufuklar açmaktadır. Esnek işletme yapılanmasına sahip işletmelerin bu sürece daha hızlı uyum sağlayabileceklerini söylemek mümkündür. Bu sayede ileri teknoloji, hız, değişen tüketici istek ve ihtiyaçlarına anında ve düşük maliyetle en akılcı uyumu sağlayabileceklerdir.

\section{Ballıpınar Çiftliği Örneği}

Afyon Ballıpınar Simental Çiftliği 2017 yılında, Afyon-Konya karayolu 30. km’de bulunan Gözsüzlü Köyü’nde kurulmuştur. TKDK desteğiyle inşa edilip, Çek Cumhuriyeti'nden ve Avusturya'dan titizlikle seçilip getirilen elit gebe düveler ile faaliyete başlamıştır. Başlangıçta 700 baş hayvandan oluşan sürü şu anda 1.100 başa ulaşmış durumdadır. Çiftlik çevresinde bulunan yaklaşık 1000 dekarlık tarım arazisinde yem ihtiyacını karşılamak amacıyla arpa, yonca, mısır, fiğ tarımı yapılmaktadır. Hayvanlardan elde edilen gübreyi tarlalarında kullanarak değerlendirmektedir. Bu sayede hem daha doğal hem de daha kaliteli ve yüksek verimli mahsul elde etmekteler. Ürettikleri yem hammaddelerini belli aralıklarla analize göndermekte ve bu sayede içeriklerine göre hazırladıkları en uygun oranlarda bileşenlerle besleme yapılmaktadır. Çiftliğin kısa vadedeki hedefi sürüyü 1200 başa çıkartmaktır. Uzun vadedeki hedefi ise, simental ırkını muhafaza ederek, çağın son teknolojilerine ayak uydurmak ve kaliteli üretime devam etmektir. Çiftlik bunun neticesinde simental gebe düve ve boğaları iç piyasaya sunmayı hedeflemektedir. Ayrıca çiftlik bünyesinde kapasiteyi karşılayacak yem fabrikası ve süt işleme tesisi faaliyete başlamış bulunmaktadır (Ballıpınar Çiftliği, 2017) .

Uludağ Üniversitesi Veteriner Fakültesi işbirliğinde embriyo aşamasında geliştirici araştırmalar da yapılmakta olduğu da girişimci tarafında ayrıca vurgulanmıştır. En verimli baş günlük 47 litreye kadar süt verebilmekte ve araştırmalar ile bu verimliliği sürdürecek ve de yükseltecek yeni nesillerin araştırılması da yapılmaktadır. 2018 yılında dönemin Gıda Tarım ve Hayvancılık Bakanı çiftliği ziyaret etmiş ve gördüğü manzara karşısında kırsalda da ümit verici gelişmelerin yaşandığını dile getirmiştir. Çiftlik sahibi tüm bu emeklerinin karşılığını henüz alamadığını, kuruluş maliyetlerinin yüksek olduğunu, elde ettikleri ürünlerde hileye başvurmadıkları için rakiplerinden daha fazla fiyata raflarda yer aldıklarını dile getirmektedir.

Girişimci tarafından çiftliğin esnek işletme yapılanmasına sahip olduğu ifade edilmiştir. Çalışmada Ballıpınar Çiftliği'nin sahibi olan girişimciye; Endüstri 4.0 hakkında bilgisi olup olmadığı sorulmuştur. Girişimcinin Endüstri 4. 0 uygulamalarının kapsamı 
konusunda bilgi donanımına sahip olduğu anlaşılmıştır. Bize çiftlikteki uygulamaları açıklarken bu teknolojinin içerdiği adımları çiftlikteki uygulamalar ile örneklendirmiştir. Konu ile ilgili kendisine bilgilendirici bir açıklama yapılmamıştır.

\section{A. Ballıpınar Çiftliği İle Yapılan Nitel Araştırmanın Amacı}

Araştırmada; çiftlik sahibi girişimcinin Endüstri 4.0 uygulamaları hakkındaki düşünceleri, çiftliğin bu teknolojiye ne kadar uyumlu olarak kurulduğu ve uygulamanın çiftlikte tamamlanma derecesi belirlenmeye çalışılmıştır.

\section{B. Ballıpınar Çiftliği İle Yapılan Nitel Araştırmanın Yöntemi}

Gözlem, mülakat ve belge incelemesi gibi veri toplama yöntemlerinin kullanıldığı nitel araştırma; algıların ve olayların doğal ortamda gerçekçi ve bütüncül bir kapsamda ortaya konulması yoluyla nitel bir sürecin izlendiği yöntemdir (Yıldırım ve Şimşek, 2006, s.39). Nitel araştırma yapılarak elde edilen bulguların sosyal gerçeklikleri açıklayıcı olarak düzenlenmesi mümkün olabilecektir (Altunışık vd., 2012, s.324). Sosyal bilimlerdeki araştırmalarda çalışılan olay ve olgular kendi ortamlarında incelenmektedir. Çünkü sosyal bilimlerde olay ve olgulara yönelik tek bir "gerçeklik" ya da tek bir "doğru” bulunmamaktadır. Çoklu gerçeklikler; farklı ve çeşitli algılar söz konusu olabilmektedir. Bu alanda, yaşanılan durumlara ilişkin katı kurallar ve genellemeler oluşturulamaz ama koşullara göre çeşitlilik gösteren betimlemeler yapılabilir (Yıldırım ve Şimşek, 2016, s.31).

Araştırmada nitel araştırma yöntemlerinden biri olarak kabul edilen "durum çalışması" yöntemi uygulanmıştır. Durumlar farklı şekillerde karşımıza çıkabilir. Bir birey, kurum, grup ya da ortam çalışılacak durumlara örnek teşkil edebilir. Durum çalışmaları nicel ya da nitel yaklaşımla yapılabilir. Her ikisinde de amaç belirli bir durumla ilgili sonuçlar ortaya koymaktır. Çalışmada duruma ait etkenler ( ortam, bireyler, olaylar, süreçler, vb.) bütüncül bir yaklaşımla araştırılır. Bu etkenlerin ilgili durumu nasıl etkiledikleri ve ilgili durumdan nasıl etkilendikleri üzerine yoğunlaşılır. Durumlar birbirinden farklı olduğu için sonuçların genellenmesi söz konusu değildir. Ancak bir duruma ilişkin elde edilen sonuçların benzer durumların anlaşılmasına yönelik örnekler ve deneyimler oluşturması beklenir (Yıldırım ve Şimşek, 2016, s.73).

Her görgül araştırma açık ya da kapalı bir araştırma desenine sahip olmaktadır. Desen; araştırma sorularını, verilerini ve sonuçta ulaşılan bulguları birbirine bağlayan mantıksal bir kurguyu ifade etmektedir. Araştırmacı için eylem planı anlamına da gelmektedir. İlk aşama, araştırmanın başında sorulan ve yanıtı aranacak soruları; son aşama ise, başlangıçta sorulan sorulara bulunan yanıtlar ya da sonuçları kapsamaktadır. Bu iki aşamanın arasında ise ilgili 
verinin toplanması ve analizini içeren bir dizi aşama yer almaktadır (Yıldırım ve Şimşek, 2016, s.292).

\section{Ballıpınar Çiftliği İle Yapılan Nitel Araştırmanın Kısıtları}

Araştırma sadece Ballıpınar Çiftliği’nde uygulanmıştır. Çiftlik sahibi girişimci ile görüşme yapılmıştır. Eylem araştırması yöntemi için yeterli olmasına rağmen, girişimde uygulama içinde yer alan diğer çalışanlara da uygulanması mümkün olabilirdi. Aynı sektörde ya da farklı sektörlerde, farklı girişimcilere uygulanmamış olması araştırmanın kısıtlarını oluşturmaktadır. Ayrıca farklı illerde aynı sektörde ya da farklı sektörlerde faaliyetlerini sürdüren girişimcilere uygulanmamış olması da kısıtlar arasında yer almaktadır. Bu kısıtlar göz önünde bulundurularak tamamlayıcı çalışmaların yapılması mümkündür.

\section{Ballıpınar Çiftliği İle Yapılan Nitel Araştırma Deseni}

Araştırma Sorusu; Esnek işletme yapılanmasına sahip bir işletmenin Endüstri 4.0 donanımına sahip bir teknolojiye uyum sağlama sürecine katkısı nasıl açıklanabilir?

Katılımcılar; Ballıpınar Çiftliği faaliyet süreci (sahibi, makine donanımı, çalışanlar ve çiftliğin bünyesindeki hayvanlar).

Veri Toplama; Girişimci ile üç ayrı zamanda her biri yaklaşık 60 dakikalık görüşmeler. Çiftliğin web sitesi, sosyal medya hesapları, basında çiftlikle ilgili yer alan bilgiler.

Örneklem; Ballıpınar Çiftliği faaliyet süreci.

\section{E. Ballıpınar Çiftliği İle Yapılan Nitel Araştırmanın Bulguları}

Afyon Ballıpınar Simental Çiftliği sahibi ve girişimci ile yapılan görüşmede; çiftliğin yüksek teknolojinin gereği olan çiftlik bilgi sistemi yazılım donanımına sahip olduğu bilgisine ulaşılmıştır. Bu donanım sayesinde çiftliğin 7/24 izlenildiği, gerekli müdahalelerin anında yapılabildiği belirtilmiştir. Bu donanım sayesinde; hayvan yönetimi, günlük işler, süt takibi, üreme, tohumlama, hastalık, muayene, yemleme oranları, sürüye bakış ve canlı izlemeyi mümkün olduğu aktarılmıştır. Ayrıca bu verilere mobil yüklemeler ile anında erişim sağlanabildiği ifade edilmiştir. Yine çiftliğin; tedarik aşamasından son tüketiciye ulaşma aşamasına kadar internet üzerinden sipariş işlemlerinin etkin olarak sürdürüldüğü ve de sosyal medyanın aktif olarak kullanıldığı vurgulanmıştır.

Çiftlik yönetimi ayrıca "mutlu hayvan; verimli süt ve et üretimi” kavramına da önem verdiklerini dile getirmiştir. Çiftlikte yer alan besi hayvanlarının her birinin cipi ve kulak numarası sayesinde anlık olarak takipleri yapılabilmektedir. Çiftlik bünyesinde; yem ve süt fabrikalarının faaliyete geçtiği, mevcut araçların yakıt ihtiyaçlarını karşılamak amacıyla da bir 
adet akaryakıt pompasının da çiftlikte yer aldı̆̆ı ve Ballıpınar Çiftliği ürünlerinin satış mağazasının da hizmete açıldığı bilgisine ulaşılmıştır.

Çiftlikteki sürünün 1.100 adetten oluştuğu, hijyen kurallarına büyük önem verildiği, mevcut makineleşmenin de bu hijyeni gerçekleştirecek titizlikte kurgulandığ Çiftlikte 30 personel bulunduğu, 2'sinin veteriner hekim, 3'ünün veteriner teknisyeni, gıda ve ziraat mühendisi, gida teknisyeni ve diğerlerinden oluştuğu belirtilmiştir.

\section{VII.Kısıtlar ve Yapılacak Çalışmalara Öneriler}

Dördüncü sanayi devrimi ya da Endüstri 4.0 oldukça yeni bir yapılanmadır. Bu nedenle bu yapılanmayı mümkün kılan girişimlere rastlamak oldukça seyrek olmaktadır. Girişimciler henüz kavram hakkında bile yeterli donanıma sahip değildir. Yapılan çalışma ile konuya farkındalık oluşturulmaya çalışılmıştır. Çalışmamızda sadece Ballıpınar Çiftliği dikkate alınmıştır. Çalışma sadece bir şehirde uygulamıştır. Farklı şehirler, farklı ülkeler, farklı sektörler dikkate alınarak çalışmanın uygulama alanını genişletmek mümkündür.

\section{Sonuç}

Hizmet sektörü ağırlıklı olan bilgi toplumunun tamamlayıcısı olarak Dördüncü Sanayi Devrimi kavramının ortaya çıktığını ifade etmek mümkündür. Endüstri 4.0 olarak da adlandırılan Dördüncü Sanayi Devrimi beraberinde güçlü bilgi donanımına sahip işgücü özelliklerini de gündeme getirmiştir. Bu işgücü yaşamboyu öğrenmeye açık, yenilikçi, yaratıcı ve yüksek reel ücret talep edebilecek donanıma sahip olmayı gerektirmektedir. Girişimciler ise, girişimlerini yapılandırırken, küresel düşünmeli, küresel ağlarda yer alabilmeli, dijitalleşmeye önem vererek zamanında esnek üretime dayalı anlayış sayesinde yenilik ve icatlara uyum sağlayabilmelidir.

Nesnelerin interneti teknolojisi sayesinde Dördüncü sanayi devrimi ya da Endüstri 4.0 "akıllı" kelimesini önemli kılmıştır. Akıllı yapılar, akıllı fabrikalar, akıllı çiftlikler gibi kavramlar da bu dönemin simgesi olarak algılanmaya başlanılmıştır. Nesnelerin interneti teknolojisi girişimcilerin, girişimlerinde uzaktan yönlendirme yapabilmeleri, daha donanımlı ancak daha az sayıda işgücünü istihdam edebilmeleri gibi pek çok yeni ve farklı bakış açılarını beraberinde getirmektedir. Teknoloji, bilgisayar ve internetin kullanımı ile hızla gelişmektedir. Endüstri 4.0 donanımı ile en iyi örtüşen yapılanmanın esnek işletme yapılanması olduğunun da altını çizmek anlamlı olacaktır. 
Endüstri 4.0 olarak adlandırılan sanayi devrimi, yeni nesil, birbiriyle iletişim kurabilen nesnelerin yer aldığı akıllı sistemler (fabrika, ev, çiftlik vb.) içeren nesnelerin interneti teknolojisi; çok sayıda, küçük boyutlu, kablosuz teknoloji kullanabilen algılayıcı aletlerin desteği ile hemen hemen bütün olayların izlenmesi ve bilgi alınması mümkün kılmıştır. Teknoloji, üretim/imalat ile ilgili endüstriyel sistemlerden aktarılabilecek gerekli verilerin eş zamanlı kullanımı da mümkün kılmaktadır. Bu sayede ortamdaki algılayıcı cihazlardan ve üretimdeki veri terminallerinden gelen, gerçek zamanlı sürekli veri akışı, internet ortamında Bulut servis sağlayıcılar tarafından verilen depolama, veritabanı, uygulama hizmetleri ile bilgi sistemleri tarafından kullanılmaya hazır hale getirilmektedir. Girişimler aşama aşama bu yapılanmaya ulaşabilir. Öncelikle Endüstri 1.0 yapılanması ile başlayan süreç sırasıyla Endüstri 2.0, 3.0 ve 4.0 yapılanmasını tamamlayabilir. Ve tüm bu yapılanmaların hızlı bir biçimde girişimlere uyarlanmasında esnek işletme modelinin varlığı önemsenmektedir. Esnek işletme modelinin sürecin başarısını destekleyeceği görüşü yaygındır.

Çalışmada yer alan çiftlik örneğindeki yapılanma göz önüne alındığında, çiftliğin Endüstri 4.0 olarak adlandırılan teknoloji ile faaliyetlerini gerçekleştirdiğini söylemek mümkün olabilir. Ayrıca girişimcinin Endüstri 4.0 uygulamalarının çiftliğine katacağı artı değerlerin farkında olduğu görüşüne ulaşılmıştır. Ancak çiftlikte yer alan hayvanların doğal ortamdan kopartılarak makineler vasıtası le yaşamlarını sürdürmeleri de farklı bir tartışmayı gündeme getirmektedir. Her ne kadar Ballıpınar Çiftliği "Akıllı çiftlik" algısı oluştursa da hayvanların yaşama özgürlüğüne akıllı teknoloji uygulaması kaynaklı bir dezavantaj oluşturmaktadır.

$\mathrm{Bu}$ akıllı çiftlik örneği sayesinde Endüstri 4.0 uygulamalarının her sektörde yapılanabileceği ancak yüksek maliyetlerinden dolayı bu yapılanma esnasında devlet desteğinin öneminin altını çizmek de gerekmektedir. Girişimcilerin bu maliyetleri karşılayabilmesi özellikle yapılanma aşamasında oldukça zor görülmektedir. Endüstri 4.0 teknolojisini uygulayan girişimlerde girişimciler; işletmelerine gitmeden, akıllı telefon ve tabletler ile uzaktan yönetebileceklerdir. Ancak Türkiye'de günümüzde henüz endüstri 4.0 uygulamalarını mümkün kılan tam donanımlı akıllı yapılar yeni yeni gündeme gelmektedir.

\section{Kaynakça}

Aktop, S. ve S. Aktop, (2017). “Gıda Endüstrisinde Akıllı Üretim Dönemi ve Endüstri 4.0”, I.Tarım ve Gıda Etiği Kongresi, Sözlü Bildiriler Kitabı, ss.135-141.

Altunışık, R., Coşkun, R., Bayraktaroğlu, S., Yıldırım, E. (2012). Araştırma Yöntemleri, Geliştirilmiş 7.Baskı, Sakarya Yayıncılık, İstanbul. 
Aydeniz, N. (1997). “Geleneksel Atölye Üretimleri ile Grup Teknolojisinin Benzeşimli Karşılaştırılması Üzerine Bir Deneme”, Adana: Çukurova Üniversitesi, İktisadi ve İdari Bilimler Fakültesi Dergisi, Cilt:7, Sayı:1.

Aytaç, Ö. ve İ. Süleyman. (2007)“Girişimcilik ve Girişimci Kültür: Sosyolojik Bir Perspektif” Selçuk Üniversitesi Sosyal Bilimler Enstitüsü Dergisi Sayı 18:101-121

Ballıpınar Çiftliği, (2017). http://ballipinarciftligi.com/dogallik-dogalarinda-var/. Erişim tarihi; 03.06.2018.

Cansız, M. (2017). 2023'e Doğru Türkiye Teknoparkları, T.C. Kalkınma Bakanlığı Yayın No:2972, Sosyal Sektörler ve Koordinasyon Genel Müdürlüğü.

Cansız, M. ve Ulusoy, D. (2017). “Teknoloji Tabanlı Girişimcilerin Başarısında Yapısal, Ekonomik, Sosyal, Kültürel ve Beşeri Sermayenin Etkileri: Türkiye Örneği”. Sosyoloji Konferansları, c. 56, s. 113-149.

Cemalcılar, İ. vd. (2000). İşletmecilik Bilgisi, İşitme Özürlü Çocuklar Eğitim ve Araştırma Vakfı Yayın No:3, Eskişehir.

Drucker, P. (2017). İnovasyon ve Girişimcilik Uygulama ve İlkeler, Çev: İ.Gülfidan, Optimist Yayınları, İstanbul.

Ercan, T ve Kutay, M. (2016). "Endüstride Nesnelerin İnterneti (loT) Uygulamaları”. AKU J. Sci. Eng. 16 (2016) 035102 (599-607).

Ergen, M. (2014). Girişimci Kapital Silikon Vadisi Tarihi ve Startup Ekonomisi, Koç Üniversitesi Yayınları, İstanbul.

Halıcı, E. (2008). “Girişimcilik ve Teknoparklar: Girişimciliğin Eski ve Yeni Yüzü”, http://www.emo.org.tr/ekler/1f860e3b7f548ab_ek.pdf, Erişim Tarihi:21.05.2018.

Kagermann, H.,Wahlster, W. Ve Helbig, J. (2013). „Recommendations for Implementing the Strategic Initiative Industrie 4.0" Final Report of the Industrie 4.0 Working Group, http://alvarestech.com/temp/tcn/CyberPhysicalSystems-Industrial4-0.pdf, Erişim Tarihi: 03.03.2019.

Karagül, M. (2010). Tehdit ve Fırsatlarıyla Dünya Ekonomisi, Nobel Yayınları, Ankara.

Marangoz, M. (2012). Girişimcilik, Beta Yayınları, İstanbul.

Marangoz, M. (2016). Girişimcilik, Genişletilmiş ve Güncellenmiş 3.Baskı, Beta Yayınları, İstanbul.

Marangoz, M. (2014). İnternette Pazarlama, Beta Yayınları, İstanbul.

Meydanoğlu, E.S.B. ve Klein M. (2016). "Nesnelerin İnterneti ve Pazarlama", Akıllı Teknoloji\&Akıllı Yönetim, Ed. V. Tecim, Ç. Tarhan ve C. Aydın, Gülermat Matbaa, İzmir, ss.12-19. 
Özdoğan, O. (2017). Endüstri 4.0 Dördüncü Sanayi Devrimi ve Endüstriyel Dönüşümün Anahtarları, Pusula Yayıncılık, İstanbul.

Özkaşıkçı, I. (2013). Dijital Çağ’da Girişimcilik Ekosistemi, İstanbul, Butik Yayıncılık.

Scarborough, N.M. (2014). Girişimciliğin ve Küçük İşletme Yönetiminin Temelleri, (Çev. Sart, G.), 7.Basımdan çeviri, Ankara: Nobel Yayınları.

Sethi, A.K. ve S.P.Sethi. (1990). "Flexibility in Manufacturing: A.Survey", International Journal of Flexible Manufacturing Systems, 2/4, ss.289-328.

Soylu, A. (2018). "Endüstri 4.0 ve Girişimcilikte Yeni Yaklaşımlar", Pamukkale Üniversitesi Sosyal Bililmler Enstitüsü Dergisi, sayı 32, Denizli, s.43-57.

Tekin, M. Ve M. Zerenler. (2007). Esnek İşletme, Nobel Yayın No:1105.

Top, A. (1996). Üretim Sistemleri, Analiz ve Planlaması, Alfa Yayınları, İstanbul.

Yıldırım A., Şimşek H. (2006). “Sosyal Bilimlerde Nitel Araştırma Yöntemleri”. 5. Baskı, Seçkin Yayınları, Ankara.

Yıldırım, A. ve Şimşek, H. (2016). Sosyal Bilimlerde Nitel Araştırma Yöntemleri, Genişletilmiş 10. Baskı, Seçkin Yayınları, Ankara.

Yuksel, A.N. ve E. Sener (2017). "The reflections of digitalization at organizational level: industry 4.0 in Turkey". Journal of Business,Economics and Finance (JBEF), V.6, Iss.3, p.291-300.

Zhao, J.C., Zhang, J.F., Feng, Y., Guo,J.X., 2010. The Study and Application of the 1OT Technology in Agriculture. 3rd IEEE International Conference on Computer Science and Information Technology (ICCSIT), 462- 465. 